\title{
Phylogenetic Relationships of the Endemic Sri Lankan Shrew Genera: Solisorex and Feroculus
}

\author{
Suyama Meegaskumbura ${ }^{1,2, *}$, Madhava Meegaskumbura ${ }^{1,2}$ and Christopher J. Schneider ${ }^{1}$ \\ ${ }^{1}$ Department of Biology, Boston University, 5 Cummington Mall, Boston, MA 02215, U.S.A. \\ ${ }^{2}$ Department of Zoology, Faculty of Science, University of Peradeniya, Sri Lanka \\ Accepted December 27, 2014
}

\begin{abstract}
Sri Lanka has a rich diversity of shrews: ten species in four genera, with two genera and five species endemic to the island. In the current study we use complete cytochrome- $b$ mitochondrial gene sequences to infer the relationships of two Sri Lankan monotypic genera Solisorex and Feroculus. Maximum likelihood and maximum parsimony phylogenetic analyses revealed that Solisorex is an old lineage that forms the sister group to all other crocidurines. In contrast, Feroculus is nested within Suncus.
\end{abstract}

Keywords: Feroculus feroculus, phylogeny, phylogeography, Solisorex pearsoni, shrews, Sri Lanka

\section{INTRODUCTION}

With 376 described species in 26 genera, shrews are among the most speciose families of mammals, representing about seven percent of the class Mammalia (Hutterer, 2005). Extant shrews are divided into three main subfamilies: Soricinae, Crocidurinae and Myosoricinae (Hutterer, 2005). The Myosoricinae were earlier included in the Crocidurinae (Repenning, 1967; Hutterer, 1993), but subsequent studies showed them to be a monophyletic group separate from the Crocidurinae and recognized at subfamilial rank by Querouil et al. (2001) and Dubey et al. (2007). Soricinae are widespread in the Holarctic region and Crocidurinae are distributed across Eurasia and Africa, while Myosoricinae are confined to Africa. Fossil evidence suggests that the soricine shrews originated in Europe (Rzebik-Kowalska, 1998). Butler et al. (1989) suggested that the Crocidurinae evolved from a Eurasian ancestor that then colonized African forests. The Myosoricinae and Crocidurinae are thought then to have diversified in Africa, with the latter dispersing into and diversifying in Eurasia (Dubey et al., 2007).

With ten species representing four genera (Suncus, Crocidura, Solisorex and Feroculus), the Sri Lankan Crocidurinae are remarkably diverse (Hutterer, 2005; Meegaskumbura et al., 2007). Of these, two genera (Solisorex Thomas, 1913; Feroculus Kelaart, 1850) and five species (Crocidura miya, C. hikmiya, Suncus fellowesgordoni, S. zeylanicus and S. montanus) are endemic to the island (Hutterer, 2005; Meegaskumbura et al., 2007; Meegaskumbura and
Schneider, 2008; Meegaskumbura et al., 2012a; Meegaskumbura et al., 2012b). Suncus, comprising 18 species, and Crocidura, with 182 species, are widely distributed in Europe, Africa and Asia. In Sri Lanka, Solisorex pearsoni and F. feroculus are confined to the highlands (Phillips, 1980). The latter species was also reported from South India (Pradan et al., 1997, Blanford, 1888), but without a preserved voucher material to confirm these records. Pradan et al. (1997) reported the Indian 'Feroculus' to have smaller bodies and longer tails than the specimens of Sri Lanka, adding further doubt to his identification.

The Crocidurinae includes five genera absent from Sri Lanka: Paracrocidura, Sylvisorex, Ruwenzorisorex, Scutisorex, and Diplomesodon (Hutterer, 2005). The first four of these are confined to the African continent whereas Diplomesodon is from Central Asia (Kazakhastan, Uzbekistan and Turkmenistan). The phylogenetic relationships of all crocidurine genera, except Diplomesodon, Feroculus and Solisorex, have been studied using partial mitochondrial $16 \mathrm{~S}$ rRNA gene sequences (Querouil et al., 2001) partial cytochrome- $b$ gene sequences and at least one nuclear gene (Stanley et al., 2013). Molecular systematic analyses to date suggest that Paracrocidura falls within the Crocidura clade, while the others show close affinities to various Suncus species. Diplomesodon was shown to fall within the clade of Crocidura by Dubey et al. (2008). The phylogenetic positions of Solisorex and Feroculus in the phylogeny of shrews remain untested using molecular data but are important for understanding the evolutionary and biogeographic history of shrews. In this study we attempt to

*Corresponding author’s email: suyamam@pdn.ac.lk 
determine the phylogenetic placement of their constituent species in the context of the other lineages of Old World crocidurine shrews using sequence data from the mitochondrial cytochrome$b$ gene.

\section{MATERIALS AND METHODS}

\section{Sampling}

All the species of shrews from Sri Lanka, except Suncus zeylanicus, were included in the study (Table 1). Voucher specimens of shrews originally deposited in the collection of the Wildlife Heritage Trust (WHT) are now in the collection of the Department of Zoology, University of Peradeniya, Sri Lanka. Tissue samples of the following specimens were obtained from museum collections (Museum of Vertebrate Zoology [MVZ], University of California Berkley and Field Museum of Natural History [FMNH], Chicago): Crocidura attenuata, $C$. fuliginosa and Euroscaptor longirostris (as an outgroup for the phylogenetic analysis) from Vietnam; Sorex araeneus (Soricinae) from Switzerland; and two Myosorex species (Myosoricinae) from Tanzania. Several additional sequences were obtained from GenBank (Table 1). All the sequences extracted from the GenBank were complete cytochrome- $b$ gene, except sequences from Stanley et al., 2013 and Demos et al., 2014, which were 684 bp and $1116 \mathrm{bp}$ fragments, respectively.

DNA extraction, amplification, and sequencing DNA was extracted from ethanol-preserved tissues using Qiagen tissue-extraction kits following manufacturer's protocols. DNA of $F$. feroculus was extracted from dried skin. The complete mitochondrial Cytochrome- $b$ gene was sequenced for all the available tissue samples. This particular mitochondrial gene was selected to facilitate analysis of the new data in the context of previously published molecular data (Motokawa, 2000; Dubey et al., 2007; Stanley et al., 2013).

DNA was amplified by PCR in $25 \mu$ reactions containing c. 50 nanograms of DNA template, 1.25 $\mu \mathrm{l}$ of each primer $(10 \mu \mathrm{M}), 2.5 \mu \mathrm{l}$ of $10 \mathrm{mM}$ dNTP, $2.5 \mu \mathrm{l}$ of $25 \mathrm{mM} \mathrm{MgCl}_{2}, 2.5 \mu \mathrm{l}$ of 10x PCR buffer, and $0.625 \mathrm{U}$ of Taq DNA Polymerase. The thermal cycling for the cytochrome- $b$ fragment was as follows: 35 cycles of denaturation at $94{ }^{\circ} \mathrm{C}$ for 30 $\mathrm{s}$, annealing at $45^{\circ} \mathrm{C}$ for $30 \mathrm{~s}$, and extension at 72 ${ }^{\circ} \mathrm{C}$ for $60 \mathrm{~s}$, with a final extension of $72{ }^{\circ} \mathrm{C}$ for 5 min. The following primers were used for PCR: Forward primer MVZ 05 (CGA AGC TTG ATA
TGA AAA ACC ATC GTTG) and reverse primer MVZ 14 (GGT CTT CAT CTY HGG YTT ACA AGAC) (Smith and Patton, 1993).

\section{Phylogenetic analysis}

Phylogenetic and molecular evolutionary analyses were conducted under the maximum likelihood (ML) criterion using MEGA version 6 (Tamura et al., 2013). The ML analysis was based on the General Time Reversible model, Gamma Distributed $(G)$ rate among sites and NearestNeighbor-Interchange (NNI) tree inference option.

The data were also analyzed under maximum parsimony (MP) criterion in PAUP*v.4.0b10 (Swofford, 2000) with all characters unordered and weighted equally. Cytochrome- $b$ sequences were aligned using the translated amino acid sequence. Three species of moles (Euroscaptor longirostris, Talpa altaica and T. europaea) were used as the outgroup because Talpidae is suggested to be proximal to shrews (Stanhope et al., 1998; Asher, 1999). A bootstrap analysis was also carried out in both ML and MP criteria to determine the node support.

\section{RESULTS}

Phylogenetic relationships inferred under maximum likelihood and maximum parsimony separately resulted in similar overall topologies except for the placement of a few species. In both trees the subfamilies were recovered as clades with high bootstrap support (BS). The clade representing the Myosoricinae (Myosorex) had a BS value of $100 \%$ in both the ML and the MP trees, and Crocidurinae had a BS of $99 \%$ (ML), $96 \%$ (MP) (Fig. 1)

Ruwenzorisorex, Scutisorex and two African Suncus species ( $S$. varilla, $S$. remyi) fall in the same clade with Sylvisorex, though with low BS $(39 \%)$ in ML tree, but in MP tree this relationship and the most of the relationships of the taxa within are unresolved. Solisorex pearsoni was recovered as the sister taxon to all the other crocidurine shrews, which are placed in a single clade with high BS values (98\% ML, 85\% MP). Placement of Myosoricinae as a sister clade to Crocidurinae is supported in the ML tree with high BS value $(92 \%)$, but it was unresolved in the MP tree. Feroculus feroculus shows close affinities to Suncus species from south and southeast Asian region in the clade of Crocidurinae. However, its relationship to other taxa in the clade does not have strong BS support. 
Table 1. Species included in this study, with country of origin, voucher number and/or GenBank accession number.

\begin{tabular}{|c|c|c|c|c|}
\hline Species & Country & $\begin{array}{l}\text { Voucher } \\
\text { number }\end{array}$ & $\begin{array}{c}\text { GenBank } \\
\text { accession } \\
\text { number }\end{array}$ & Reference \\
\hline Crocidura attenuata & Vietnam & MVZ185237 & EU122211 & Meegaskumbura et al., 2007 \\
\hline C. fuliginosa & Vietnam & MVZ186404 & EU122212 & Meegaskumbura et al., 2007 \\
\hline C. hikmiya & Sri Lanka & WHT 6853 & EU122223 & Meegaskumbura et al., 2007 \\
\hline C. horsfieldii & Sri Lanka & WHT 6869 & EU122213 & Meegaskumbura et al., 2007 \\
\hline C. miya & Sri Lanka & WHT 6826 & EU122216 & Meegaskumbura et al., 2007 \\
\hline Feroculus feroculus & Sri Lanka & WHT 6827 & JQ433898 & This study \\
\hline Solisorex pearsoni & Sri Lanka & $\begin{array}{l}\text { WHT } 6810 \\
\text { WHT M } 184\end{array}$ & $\begin{array}{l}\text { JQ433899 } \\
\text { JQ433900 }\end{array}$ & This study \\
\hline Suncus fellowesgordoni & Sri Lanka & WHT 6820 & JF914983 & Meegaskumbura et al., 2012a \\
\hline S. etruscus & Sri Lanka & WHT 6936 & FJ716836 & $\begin{array}{l}\text { Meegaskumbura and } \\
\text { Schneider, } 2008\end{array}$ \\
\hline S. etruscus & France & - & JF817396 & Omar et al., 2011 \\
\hline$S$ varilla & Africa & - & DQ630434 & Dubey et al., 2007 \\
\hline S. remyi & Africa & - & DQ630399 & Dubey et al., 2007 \\
\hline S. murinus & Sri Lanka & WHT 6928 & EU122224 & Meegaskumbura et al., 2007 \\
\hline S. stoliczkanus & Nepal & - & AB175077 & Ohdachi et al., 2004 \\
\hline S. dayi & India & - & DQ630432 & Dubey et al., 2007 \\
\hline Ruwenzorisorex suncoides & Africa & $\begin{array}{l}\text { FMNH } \\
157830\end{array}$ & KF110750 & Stanley et al., 2013 \\
\hline Scutisorex somereni & Africa & - & KF110752 & Stanley et al., 2013 \\
\hline Sc. thori & Africa & $\begin{array}{l}\text { FMNH } \\
219669\end{array}$ & KF110765 & Stanley et al., 2013 \\
\hline Sylvisorex granti & Africa & $\begin{array}{l}\text { FMNH } \\
209792\end{array}$ & KF876413 & Demos et al., 2014 \\
\hline Sy. lunaris & Africa & $\begin{array}{l}\text { FMNH } \\
203754\end{array}$ & KF876415 & Demos et al., 2014 \\
\hline Sy. ollula & Africa & - & DQ630398 & Dubey et al., 2007 \\
\hline Sy. cf. vulcanorum & Africa & $\begin{array}{l}\text { FMNH } \\
189110\end{array}$ & KF876463 & Demos et al., 2014 \\
\hline Sy. vulcanorum & Africa & $\begin{array}{l}\text { FMNH } \\
189114\end{array}$ & KF876465 & Demos et al., 2014 \\
\hline Sy. johnstoni & Africa & - & DQ630392 & Dubey et al., 2007 \\
\hline Myosorex zinki & Africa & $\begin{array}{l}\text { FMNH } \\
174124\end{array}$ & JX193702 & Kang et al., 2014 \\
\hline M. geata & Africa & $\begin{array}{l}\text { FMNH } \\
158299\end{array}$ & JQ433901 & This study \\
\hline M. kihaulei & Africa & $\begin{array}{l}\text { FMNH } \\
155611\end{array}$ & JQ433902 & This study \\
\hline Soriculus fumudus & Taiwan & GU 981278 & AY033086 & Fang, 2001 \\
\hline Soriculus nigrescens & & & GU981300 & He et al., 2010 \\
\hline Sorex araeneus & Switzerland & MVZ 155871 & EU122225 & Meegaskumbura et al., 2007 \\
\hline Talpa altaica & & & AB037602 & Tsuchiya et al., 2000 \\
\hline Talpa europaea & Europe & - & $\mathrm{AB} 037601$ & Tsuchiya et al., 2000 \\
\hline Euroscaptor longirostris & Vietnam & MVZ 186406 & EU122226 & Meegaskumbura et al., 2007 \\
\hline
\end{tabular}




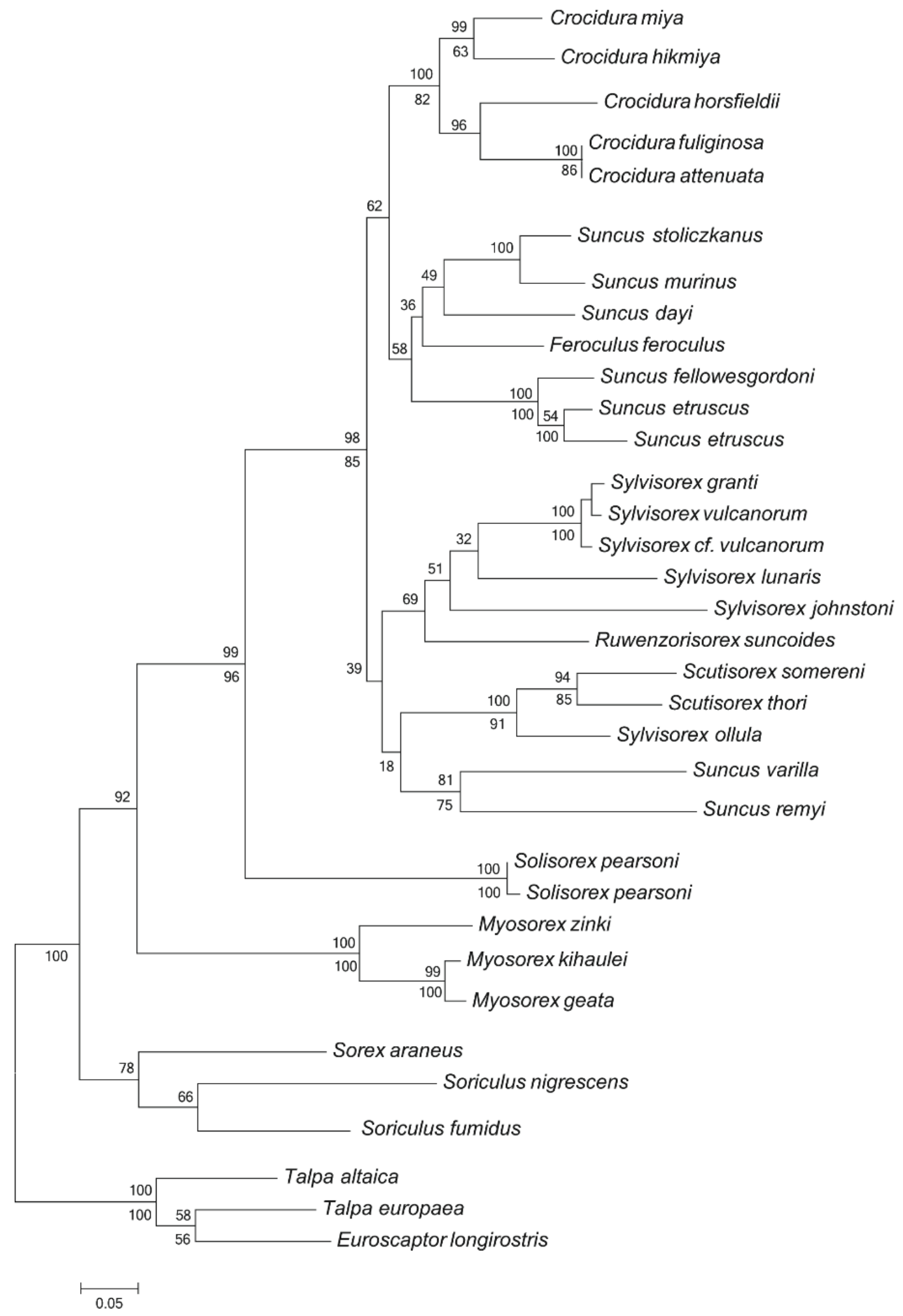

Figure 1. Maximum likelihood tree from MEGA version 6 of cytochrome- $b$ sequence data with bootstrap values shown above branches. Bootstrap values obtained from maximum parsimony in PAUP*v.4.0b10 are given below the branches. Nodes without MP bootstrap values are those that were unresolved in the MP tree. 


\section{DISCUSSION}

Though resolution of evolutionary relationships among taxa using DNA-sequence data has become an increasingly powerful method, only two studies so far have included a majority of crocidurine lineages in a molecular phylogeny. Querouil et al. (2001) included all African crocidurine genera except Surdisorex, while Dubey et al. (2007) included species from the Soricinae and representatives of three crocidurine genera (Suncus, Crocidura and Sylvosorex). The present study includes two monotypic genera, Solisorex and Feroculus.

The placement of the Myosoricinae has been ambiguous in the literature (Repenning, 1967; Hutterer, 1993; Querouil et al., 2001; Dubey et al., 2007). In this analysis, the Soricinae, Myosoricinae and Crocidurinae were all reciprocally monophyletic with high $\mathrm{BS}$, with the Myosoricinae forming the sister group to Crocidurinae in the ML tree but not in MP tree. Querouil et al. (2001) found that the Myosoricinae formed the sister group of Soricinae, albeit with low bootstrap support (58\%). The placement of Myosoricinae as the sister group to Crocidurinae was also observed by Dubey et al. (2007), who used $3314 \mathrm{bp}$ of mitochondrial (cytochrome- $b$ and 16S rRNA) and nuclear genes (BRCA1 and ApoB) sequences to construct the phylogeny. However, they did not recognize Myosoricinae as a separate subfamily, arguing that the branch lengths among the crocidurine shrews and myosoricine shrews are similar to those seen among some of the tribes in Soricinae. Regardless of the Linnaean taxonomic rank assigned, the currently recognized subfamilies, including the Myosoricinae, are clearly monophyletic. Similar to our ML tree, the placement of Ruwenzorisorex, Scutisorex and African Suncus species (S. remyi, S. megalura) with Sylvisorex in a single clade was reported by Stanley et al. (2013), based on partial sequences from the von Willebrand factor Exon 28 gene. However, Scutisorex is placed as a sister taxon to other crocidurine shrews (Ruwenzorisorex, Suncus, Sylvisorex and Crocidura) in a partial cytochrome- $b$ gene tree (Stanley et $a l ., 2013$ ). In both studies, however, the relationships among these taxa is not well resolved nor strongly supported.

The inclusion of the Sri Lankan endemic genera in the phylogeny revealed that Solisorex is indeed an ancient lineage: it forms the sister taxon to all the other crocidurine shrews. This relationship is well supported in both MP and ML trees. The position of $S$. pearsoni suggests an African origin for Solisorex and a dispersal event from Africa to Sri Lanka. It also suggests that there may have been numerous extinctions of shrews after the period in which Solisorex and other African genera evolved, as there are no species or genera that show phylogenetic or morphological affinities to these genera in the Indian subcontinent or regions between Sri Lanka and Africa. Morphological characters of Solisorex also support the placement of Solisorex between myosoricine shrews and crocidurine shrews (Nowak, 1999). Morphologically, Solisorex and myosoricine shrews (e.g., Myosorex, Congosorex and Surdisorex) share several characters: lack of long scattered hairs on the tail, larger manus claws, and three unicuspid teeth on the upper jaw instead of four as in the others. Other Crocidurinae genera share at least one of the above characters with Myosoricinae and Solisorex. For example, Sylvisorex, Ruwenzorisorex and Scutisorex lack long scattered hairs on the tail but have small claws and four unicuspid teeth; Feroculus have large manus claws but lack the other two characters; Suncus species do not share any of these characters with Myosoricinae and Solisorex, except S. day, which lacks long scattered hairs on the tail. Crocidura/Paracrocidura species share the same number of unicuspid teeth with Myosoricinae and Solisorex, and long tail hairs are present in some species but not others.

Feroculus feroculus shows closer phylogenetic affinities to Suncus species than to any of the other genera studied. Morphologically, Feroculus and Suncus share the same number of upper jaw teeth (18), with 4 unicuspid teeth and tails with long scattered hairs (except for $S$. dayi, which lacks these) on the tail. There are, however, distinct morphological characters that support the recognition of Feroculus as a distinct genus: large manus claws (as in Solisorex) and fully furred ears, whereas Suncus has small manus claws and seminaked ears. Feroculus is also semi-aquatic, whereas Suncus is a land dweller (Phillips, 1980).

In summary, our analysis finds that Solisorex is an ancient lineage forming the sister taxon to all the other crocidurine shrews suggesting an African origin for the genus while Feroculus shows close affinities to south and southeast Asian Suncus species. This is the first attempt to investigate the phylogenetic position of these two monotypic genera. The lack of resolution in the phylogeny clearly points to the need for both greater taxonomic representation as well as increased data from the nuclear genome.

\section{ACKNOWLEDGMENTS}

We thank Rohan Pethiyagoda (WHT) for providing resources and logistical support during 
the project; Mohomed Bahir and Sudath Nanayakkara (WHT) for assistance with field work; the Department of Wildlife Conservation, Sri Lanka, for granting permits to collect specimens and to export tissue samples for analysis at Boston University; the Forest Department, Sri Lanka, for granting permits to work in forest reserves; Carla Cicero of the Museum of Vertebrate Zoology, University of California, Berkley for kindly providing tissue samples of several species; Paula Jenkins of The Natural History Museum (NHM), London, for permission to examine type specimens in her care; and Fred Naggs, Daphnie Hills and Louise Tomsett (NHM) for hospitality and generous assistance extended to us during visits to their institution.

\section{REFERENCES}

Asher, R. J. (1999). A morphological basis for assessing phylogeny of the "Tenrecoidea" (Mammalia, Lipotyphla). Cladistics 15: 231251.

Blanford, W. T. (1888). Fauna of British India, Mammalia. Taylor and Francis: London.

Butler, P. M., Thorpe, R. S. and Greenwood, M. (1989). Interspecific relations of African crocidurine shrews (Mammalia: Soricidae) based on multivariate analysis of mandibular data. Zoological Journal of the Linnean Society 96: $373-412$.

Demos, T. C., Kerbis Peterhans, J. C., Agwanda, B. and Hickerson M. J. (2014). Uncovering cryptic diversity and refugial persistence among small mammal lineages across the Eastern Afromontane biodiversity hotspot. Molecular Phylogenetics and Evolution 71: 41-54.

Dubey, S., Salamin, N., Ohdachi, S. D., Barrière, P. and Vogel, P. (2007). Molecular phylogenetics of shrews (Mammalia: Soricidae) reveal timing of transcontinental colonization's. Molecular Phylogenetics and Evolution 44: 126-137.

Dubey, S., Salamin, N., Ruedi, M., Barrière, P., Colyn, M. and Vogel, P. (2008). Biogeographic origin and radiation of the Old World crocidurine shrews (Mammalia: Soricidae) inferred from mitochondrial and nuclear genes. Molecular Phylogenetics and Evolution 48: 953-963.

Fang, Y. P. (2001). Mitochondral cytochrome- $b$ sequence of Soriculus fumidus Thesis, National Taiwan University, Department of Zoology, No. 1, Section 4, Luosfu Rd., Taipei 106, Taiwan.

He, K., Li, Y. J., Brandley, M. C., Lin, L. K., Wang, Y. X., Zhang, Y. P. and Jiang, X. L. (2010). A multi-locus phylogeny of
Nectogalini shrews and influences of the paleoclimate on speciation and evolution. Molecular Phylogenetics and Evolution 56 (2): 734-746.

Hutterer, R. (1993). Order Insectivora. In: Wilson, D. E. and Reeder, D. M. (eds.) Mammal Species of the World, Second Edition. Smithsonian Institution Press, Washington and London Pp. 69-130.

Hutterer, R. (2005). Order Soricomorpha. In: Wilson D. E. \& Reeder, D. M. (Eds.) Mammal species of the world: a taxonomic and geographic reference. Third Edition. The Johns Hopkins University Press, Baltimore, Pp. 220-311.

Kang, H. J., Stanley, W. T., Esselstyn, J. A., Gu, S. H. and Yanagihara, R. (2014). Expanded Host Diversity and Geographic Distribution of Hantaviruses in Sub-Saharan Africa. Journal of Virology 88 (13): 7663-7667.

Meegaskumbura, S., Meegaskumbura, M., Pethiyagoda, R., Manamendra-Arachchi, K. and Schneider, C. J. (2007). Crocidura hikmiya, a new shrew (Mammalia: Soricomorpha: Soricidae) from Sri Lanka. Zootaxa 1665: 19-30.

Meegaskumbura, S. and Schneider, C. J. (2008). A taxonomic evaluation of the shrew Suncus montanus (Soricidae: Crocidurinae) of Sri Lanka and India. Ceylon Journal of Science 37(2): 129-136.

Meegaskumbura, S., Meegaskumbura M. and Schneider, C. J. (2012a). Re-evaluation of the taxonomy of the Sri Lankan pigmy shrew Suncus fellowesgordoni (Soricidae: Crocidurinae) and its phylogenetic relationship with S. etruscus. Zootaxa 3187: 57-68

Meegaskumbura, S., Meegaskumbura M. and Schneider, C. J. (2012b). Phylogenetic position of Suncus fellowesgordoni with pigmy shrews from Madagascar and Southeast Asia inferred from cytochrome- $b$. Ceylon Journal of Science 41 (1): 83-87.

Motokawa, M., Suzuki, H., Harada, M., Lin, L. K., Koyasu, K. and Oda, S. (2000). Phylogenetic relationships among East Asian speciesof Crocidura (Mammalia, Insectivora) inferred from mitochondrial cytochrome $b$ gene sequences. Zoological Science 17: 497-504.

Nowak, R. M. (1999). Walker's Mammals of the World. Sixth edition. The John Hopkins University Press, Baltimore and London.

Ohdachi, S. D., Iwasa, M. A., Nesterenko, V. A., Abe, H., Masuda, R. and Haberl, W. (2004). Molecular phylogenetics of Crocidura shrews (Insectivora) in East and Central Asia. Journal of Mammalogy. 85: 396-403.

Omar, H., Adamson, E.A.S., Bhassu, S., Goodman, S.M., Soarimalala, V., Hashim, R. and Ruedi, M. (2011). Phylogenetic 
relationships of Malayan and Malagasy pygmy shrews of the genus Suncus (Soricomorpha: Soricidae) inferred from mitochondrial cytochrome b gene sequences. Raffles Bulletin of Zoology 59 (2): 237-243.

Phillips, W. W. A. (1980). A manual of the mammals of Sri Lanka. Wildlife and Nature Protection Society of Sri Lanka, Colombo Pp 389+xxxv.

Pradhan M. S., Sharma R. M. and Shankar K. (1997) First record of Kelaart's long-clawed shrew, Feroculus feroculus (Kelaart) (Insectivora, Soricidae, Crocidurinaae) from Peninsular India. Mammalia. 61(3): 448-450.

Querouil, S., Huttere, R., Barriere, P., Colyn, M., Peterhans, J. C. K. and Verheyen, E. (2001). Phylogeny and evolution of African Shrews (Mammalia:Soricidae) inferred from 16s rRNA sequences. Molecular Phylogenetics and Evolution 20(2): 185-195.

Repenning, C. A. (1967). Subfamilies and genera of the Soricidae. Geological Survey Professional Paper 565: 1-74.

Rzebik-Kowalska, B. (1998). Fossil history of shrews in Europe. In: Wojcik, J.M.; Wolsan, M., eds., Evolution of shrews. - Mammal Research Institute, Polish Academy of Sciences: 23-92.

Smith, M. F., Patton, J. L. (1993). The diversification of South American murid rodents: evidence from mitochondrial DNA sequence data for the akodontine tribe. Biology Journal of Linnean Society 50: 149-177.
Stanhope, M. J., Waddell, V. G., Madsen, O., De Jong, W., Blair Hedges, S., Cleven, G. C., Kao, D. and Springer, M. (1998). Molecular evidence for multiple origins of Insectivora and for a new order of endemic African insectivore mammals. Proceedings of the National Academy of Sciences, U.S.A. 95: 9967-9972.

Stanley, W. T., Robbins, L. W., Malekani, J. M., Mbalitini, S., Migurimu, D. A., Mukinzi, J. C., Hulselmans, J., Prevot, V., Verheyen, E., Hutterer, R., Doty, J. B., Monroe, B. P., Nakazawa, Y. J., Braden, Z., Carroll, D., Kerbis Peterhans, J. C., Bates, J. M. and Esselstyn, J. A. (2013). A new hero emerges: another exceptional mammalian spine and its potential adaptive significance. Biology Letters 9(5): 20130486. Doi: 10.1098/rsbl.2013.0486.

Swofford, D. L. (2000). PAUP* 4.0 Phylogenetic analysis using parsimony (and other methods), Sinauer Associates, Sunderland, CD-ROM.

Tamura, K., Stecher, G., Peterson, D., Filipski, A. and Kumar, S. (2013). MEGA6: Molecular Evolutionary Genetics Analysis version 6.0. Molecular Biology and Evolution 30 27252729.

Tsuchiya, K., Suzuki, H., Shinohara, A., Harada, M., Wakana, S., Sakaizumi, M., Han, S. H., Lin, L. K. and Kryukov, A. P. (2000). Molecular phylogeny of East Asian moles inferred from the sequence variation of the mitochondrial cytochrome b gene. Genes and Genetic Systems 75(1): 17-24. 